\title{
Fostering the Economic Tourist Activity of Small Cities by Managing Retail Town Centre Image
}

\author{
Montserrat Díaz-Méndez, PhD \\ Luís Ceia, PhD \\ José Manuel García-Gallego, PhD
}

University of Extremadura

Spain

\begin{abstract}
This research aims to examine the relationship between the town centre retail and the town image. We study the influence the retail activity of a town centre may have on the town image. Particularly, we analyze the factors influencing town centre retail dynamics, how these factors relate to each other and how their variation can influence the image of the town centre. A theoretical model is proposed and tested through a case study applied to the Portuguese town of Viana do Castelo.
\end{abstract}

Keywords: Town Destination Image, Retail Image, Shopping Destination and Town Centre Management

\section{JEL classification: M39}

\section{Introduction}

The town centre is the zone of the city where the best and largest variety of stores are concentrated. The town centre "holds the power of representation and perception of the present town because the symbols that shape the town identity are fixed in it" (Peixoto, 2003: 217). It usually holds the great majority of the patrimony of a city. Creating a positive image of a town often implies improving the living conditions of the local population and other actors; and a positive emotional perception of the town may contribute to improving town image (Wang, 2009; Westwood and Williams, 2018). The use of marketing in the management of town development can help to achieve this positive perception and the creation of a good town image. Town marketing is more than the mere promotion of a place, it is used in some cities to rebuild and redefine their image (Paddison, 1993). A good town image will provide significant benefits that will allow a territory to better sell their intrinsic characteristics to attract economic activities such as investments or tourism (Westwood and Williams, 2018). Traditionally, town marketing strategies have been characterized by increasing sophistication and professionalism (Ward, 1998) within an inter-town competition environment (Kotler,1999).

The application of marketing principles to town centre retail is a contribution for the revitalization of town centres, providing value to consumers through a retail offer that is accessible, attractive, differentiated and varied (Warnaby, 1998). However, despite the growing importance of town marketing in recent years, the marketing and promotion of town retail centres has not been properly emphasized. Entities traditionally responsible for town marketing have focused their attention on attracting domestic investment and revenues of tourism (Warnaby and Medway, 2004). The role of town centre retail as a support to all other town valences and especially as a tool to foster tourists attraction has been largely ignored in the literature (Warnaby et al., 2004), although some authors (Shaw and Williams, 1994) agree that the supply of town centre retail should be considered a priority attraction for most town centres. Thus this research aims to contribute to theory creation on town destination image by examining the influence of town centre retail on the global image of the city and its potential to increase tourist activity especially in small and medium-size towns. There are many studies about the image of a city but none of them deals with the influence of the town centre retail on its image. In this way, it is important to find out to what extent the town centre retail is a preponderant element in the image of the city.

The methodology used in this study refers to a case study research conducted in a town from Portugal named Viana do Castelo. The information was collected through in-depth interviews and telephone interviews by the CATI (Computer Assisted Telephone Interviewing) system, based on the questionnaire elaborated specifically for this study. The structure of this article is as follows: first, we carry out a literature review on town centre management, town centre retail, image of the town and destination image. Then, we propose a theoretical model based on literature. Next, the theoretical model is tested using a univariable method. We conduct a case study focused on the city of Viana do Castelo. Finally, we discuss the results and present the conclusions of the study. 


\section{Theoretical background}

\subsection{Town centre retail}

The concept of town centre retail embraces the shopping activities that take place in a town context. It includes not only the traditional retail units, but also those operating as a mono brand, franchise or agency. According to Fernandes et al. (2001) the town centre retail can be defined as "a relatively homogeneous model, focused on small family businesses and traditional retail forms that in few years are turning into another model with strong bipolar characteristics". On one hand, we find spaces which we can call internationalized, dominated by large distribution chains (foreign and domestic) and franchising networks, oriented to specific market segments. On the other hand, we find local spaces supported mainly by small and medium enterprises (SMEs).

The town centre retail management is closely related to the town centre characteristics in which it is located. Retail and town centre have grown side by side, and they influence each other (Balsas, 2002).

Since years ago, different countries, local authorities, economic agents, and residents have become aware of the need to revitalize town centre trying to find models that can respond to this concern (Diamond et al., 2010). These initiatives can be grouped basically into two types according to their origin: (1) the American experiences that are based on BID(Business Improvement District)and (2) the European Experiences supported by TCM (Town Centre Management) (Balsas,2004).

A BID is a partnership, public or private, in which owners and shopkeepers participate in a collective effort to maintain, develop and promote their shopping district. It is a financial instrument that allows the owners of a zone to obtain additional services for their geographical zone through the taxation of their commercial properties. BIDs are formed and controlled by the owners of a specific zone (Balsas, 2002). A TCM is an informal form of partnership, public or private, that focuses on strategic development and promotes its activities coordinating the interests of different stakeholders. TCMs are financed by the public and private sectors and their action must be innovative and proactive to adapt to constant new challenges ${ }^{1}$

\subsection{Destination image and image of the town}

Brand image is considered a subjective phenomenon that is formed through the interpretation of the consumer, which can be rational or emotional (Dobniand Zinkhan, 1990).It is not then inherent to the technical, functional and physical concerns of the product. Rather it is affected and shaped by marketing activities, contextual variables and the personal characteristics of observers (Dobniand Zinkhan, 1990). In the case of territories, the destination image can be defined as a mental representation of the beliefs, feelings and global perception about a destination (Las Casas and Silverio, 2015). The destination image plays two important roles on behavior: it influences the process of choice of destination and conditions subsequent decisions that determine behavior such as participation, evaluation and future intentions to visit and recommend the destination (Bigné and Sanchez, 2001; Las Casas and Silverio, 2015). According to Warnaby et al. (2002), the destination image is one of the most valuable tools for professionals to analyze the territories as tourist destinations. Trueman et al.(2004) contend that a poor perception of the image of a town can devalue its image and have great consequences for its future prosperity. These negative associations can reduce the likelihood of capturing investments, impairing local economic activities and have a significant effect on the number of visitors. By contrast, an improved image or perceived brand reinforced by visual evidence or progress within the town can reverse a downward trend and sow the seeds of town regeneration. The destination brand approach is very different from traditional destination promotion, which essentially uses physical attributes and activity opportunities (Moscardo, 2008). Travelling has more and more to do with experiences and with personal fulfillment than with things and places (King, 2002; Andersson and Abbasian, 2018).

\subsection{Variables influencing destination image}

According to Neacşu and Negut (2012) the construction of town destination image implies the existence of two entities: (1) the town, with its elements, forms, processes and phenomena, in a perceived permanent dynamic of different scales, and (2) the receiver (residents and non-residents), who perceives the town through its own variables selecting, organizing and taking the town information.

Several authors have focused on the factors determining the town destination image. According to the information showed in table 1, most researchers agree that most of these factors should be considered when speaking about town destination image.

\footnotetext{
${ }^{1}$ http://www.tocema-europe.com/
} 
Table 1. Factors influencing destination image of the town

\begin{tabular}{|c|c|}
\hline Author & Dimensions \\
\hline Ashworth and Voogd (1990) & $\begin{array}{l}\text { Promotion measures; } \\
\text { Spatial measures; } \\
\text { Financial and organizational measures. }\end{array}$ \\
\hline Kotler and Amstrong (2018) & $\begin{array}{l}\text { Design (the place with a character); } \\
\text { Infrastructure (place enabling environments); } \\
\text { Basic services (place as supplier); } \\
\text { Attractions (place of entertainment and recreation). }\end{array}$ \\
\hline Hall and Hubbard (1998) & $\begin{array}{l}\text { Advertising and promotion; } \\
\text { Scale of physical regeneration; } \\
\text { Public art and civic statuary; } \\
\text { cultural regeneration; } \\
\text { Public-private partnerships. }\end{array}$ \\
\hline Avraham (2004) & $\begin{array}{l}\text { Size of the population and space; } \\
\text { Status or to political; } \\
\text { Rate of criminality; } \\
\text { Number and nature of national institutions located in } \\
\text { the town; } \\
\text { Its location; Its history; } \\
\text { Value tourist and cultural; } \\
\text { Movies and TV series that was filmed in the town; } \\
\text { The volume of the coverage by the media of } \\
\text { communication; } \\
\text { Natural beauty and heritage. }\end{array}$ \\
\hline Kavaratzis (2004) & $\begin{array}{l}\text { Advertising and promotion; } \\
\text { Scale of physical regeneration; } \\
\text { Public art and civic statuary; } \\
\text { Cultural regeneration; } \\
\text { landscape and town design } \\
\text { infrastructures } \\
\text { Public-private partnerships. }\end{array}$ \\
\hline $\begin{array}{l}\text { Eghbali, Kharazmi } \\
\text { Rahnama (2015) }\end{array}$ & $\begin{array}{l}\text { Culture / history; } \\
\text { Transport and communications; } \\
\text { Architecture } \\
\text { Environment; range of service. }\end{array}$ \\
\hline Dinardi (2015) & Cultural policies \\
\hline
\end{tabular}

Source: the authors

According to the extant literature, key variables of the destination town image could be grouped in the following categories: town centre retail, landscape and town design, spatial infrastructure, town activities, organization/management and town centre and communication. However, in this research we will focus on the matrix of the four A's framework, introduced by the influential publication Vital and Viable town Centre - Department of the Environment of $U K$ (DoE, 1994), which groups variables that can affect town centre town retail in four main factors: Accessibility; Attraction type landmarks/points of interest; Amenities and Action management. Considering the impact and relevance of this matrix and reviewing the literature, it is possible to redefine critical success factors of the town centre retail from the original framework of the 4 A's according to Díaz (2004),ATCM (2018) and Nair (2018), thus these variables would comprise the following aspects:

Accesibility: location, existence of sufficient parking, pedestrianization of the streets, ease of access by public transport. Attractions: retail mix, presence of a large number of establishments, quality of products for sale, well-known brands and franchises, additional offer, leisure establishments, bars and restaurants, presence of real estate, banks, insurance. Amenities: attractive buildings, exhibitions on the streets, town furniture adapted to the environment, safety, adequate signage of the shopping zone, consumer services, image of the town. 
Action: management professionalization, exclusive management dedication, interest in consumer satisfaction and loyalty, public relations, promotion and communication campaigns, active collaboration, management of empty premises.

\section{Empirical research}

\subsection{Objectives}

This research intends to analyze the influence of the town centre retail on the image of a town. It seeks to identify and describe the factors that influence the retail dynamics of the town centre, and in turn, to assess the impact of town centre on the image of the town. The following specific objectives are presented:

a. Identify the factors that influence the retail image of the towncentre;

b. Analyze the impact of the towncentre retail image on the towncentre image;

c. Identify the dimensions that influence the image of a town.

\subsection{Proposed model and hypotheses}

The construction of the model presupposes the isolation of certain phenomena and the reduction of the complexity of real situations, simplifying them in order to apply the most relevant variables relations.

Variants of application of the peer-to-peer correction technique are proposed and analyzed by means of experiments looking for one that maximizes the objectivity of the resulting qualifications. The association between variables should not be understood as a question of all or nothing, but as a continuum from the absence of relation (independence) to the maximum level of relationship between variables. This maximum degree would be expressed in a deterministic relation, that is, in the case in which from the value of any subject in a variable, it can be stated what its value will be in the other variable.

The study suggests a model that identifies indicators that can influence the independent variables, the antecedent variable - image of the towncentre retail and directly in the final variable - image of the town (See Figure 1).

Figure1.Proposed model: variables influencing town image

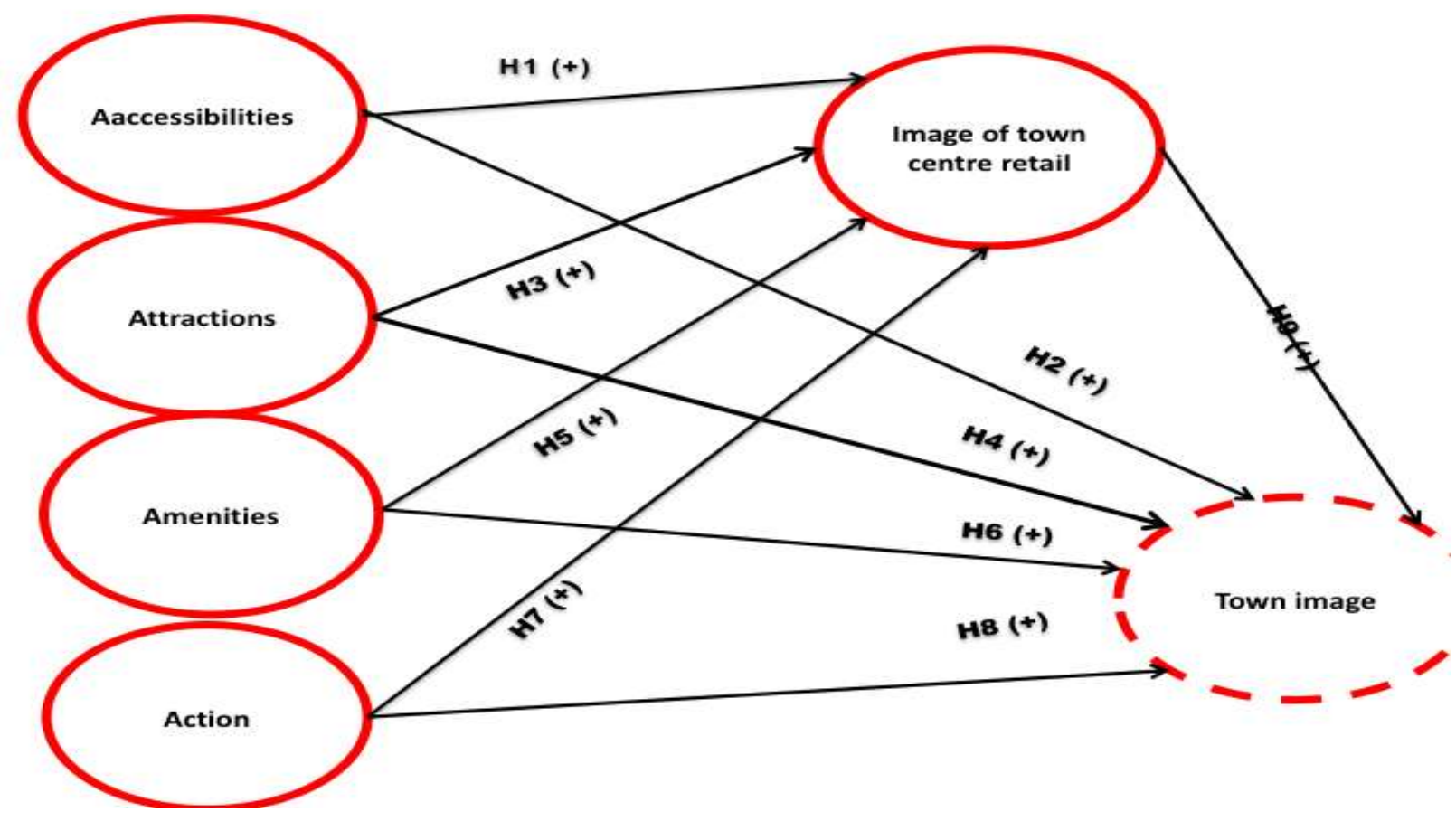

The following hypotheses result from the proposed model:

H1: The town centre accessibility positively influences the image of the town centre retail.

$\mathrm{H} 2$ : The town centre accessibility positively influences the image of the town.

H3: An attractive town centre positively influences the image of the town centre retail.

H4: An attractive town centre positively influences the image of the town.

H5: The town centre amenities positively influence on the image of the town centre. 
H6: The town centre amenities positively influences the image of the town.

H7: The town centre management positively influences the image of the town centre retail.

H8: The town centre management positively influences the image of the town.

H9: A good image of the town centre retail positively influences the image of the town.

Hypotheses 1 and 2- The location of retail centres has been considered a strategic factor in the decisions to be taken when deciding to open a new shopping zone. Consumer choice is influenced enormously by location, which denotes a relationship between consumer perception of utility and fate characteristics (Fotheringham and O'Kelly, 1989). Commercial spaces should be prepared to develop sustainable competitive advantages through strategic locations (Collis et al., 2000). Accessibility in this context is defined as the ease of entering and exiting a retail centre (Levy and Weitz, 2007). This factor considers not only the spatial and temporal dimensions that assess the ease and speed with which it reaches the intended place, in this case the retail zone, but also considers the obstacles that can be placed in this path, such as traffic jams, frequency of public transportation schedules, and works on access roads (Ingene, 1984).Town car parks appear as an essential complement to this multimodal transport policy, so that their existence or not, whether free or not, clearly influences the behavior of today's consumers. As evidenced by Brown (1990: 19), "(...) the three most important properties of a retail zone are: location, location, and location. In a competitive environment, location can have a significant impact on market share to achieve, creating an advantage that can mitigate some of the shortcomings that the retail mix may have (Ghosh and McLafFerty, 1987).

Hypotheses 3 and 4 -The variety and quantity of products offered in a retail zone is referenced as determinant of consumer buying behavior (Cerdá Suárez et al., 2007).

Instead of analyzing each retail per se, account should be taken of the entire shopping offer, which also includes aspects such as the social and recreational value of the location zone (Warnaby and Davies, 1997), Warnaby, and Medway, 2004). According to Cerdá Suárez et al., (2007) the contribution of other aspects of the retail mix, such as the existence of public services, banks and locomotive shops, should also be taken into account. The overall attractiveness of the whole place is undoubtedly a factor to be considered in the decision of the consumers, and therefore in the perceived image of the towncentre retail.

Hypotheses 5 and 6 - There is a set of attributes and services that can provide a favorable environment for shopping activities. Authors designate these as amenities. Cerdá Suárez et al., (2007: 20) contend that it influences the image that the consumers perceive of the centre "(...) through the presence of attractive buildings, unified furniture, animation and adequate signage in the zone. To these attributes, others must also be joined, such as the presence of frequent joint promotions, shared services for consumers (home deliveries, free bus to the centre, discounts in a parking lot ..., plus security and Cleaning (Warnaby, 1998).

Hypotheses 7 and 8 - There is a consensus among academics and professionals about the importance and the need for a unified management of the activities carried out in a commercial area. A professional management could build bridges between the merchant, the owners and the entities located in the center of the town. According to the literature, results would involve the attraction of visitors, residents and buyers to town centre (Stubbs, Warnaby, and Medway, 2002; Hogg and Penz, 2007).

Hypothesis 9 - The town centre will always be confused with the places where the main town activities are concentrated "The town centre is the zone that normally creates the first impressions of visitors to the town" (Balsas, 2002: 12). The centre was built due to the concentration of different functions: commercial, public and private management, leisure, material and symbolic values. While the periphery is negatively defined in terms of these functions. For Kinley et al. (2002) when choosing a shopping destination for tourists or visitors, there are some aspects specially important such as: local atmosphere, kindness of the service, cleanliness, safety, environment pleasant and a comfortable playground. The importance of town centre retail for the development of the town economy is being recognized (ATCM, 1994) starting to play a role as "(...) catalyst for town regeneration" (Warnaby et al., 2003: 884). Many authors acknowledge the importance of town marketing, but consider that retail marketing, made by the various public and private agencies operating in town centre, continues to be done individually and inarticulate (Warnaby, 2000). The old idea that town centre is only the financial centre of business of towns has been replaced by the idea that the centre is a central place for the whole community. The centre appears as a space that reflects the cultural heritage of a community, presenting multidisciplinary functions such as shopping, recreation, fun, work, residential, etc. (Robertson and Ryan, 2004). The town centre plays a crucial role in the dynamics of the town. The centres are vibrant economic stimuli for the local economy, in addition to attracting visitors and tourists to the town. A considerable part of the income of a municipality comes from the economic activity of its towns centre (Wang, 2009). 


\section{Methodology}

\subsection{Case study applied to the town of Viana do Castelo}

Viana do Castelo is a town of North Portugal with a population of approximately 46,000 inhabitants representing more than half of the total population of the municipality. The town is the most important town of the Alto Minho Region. Viana do Castelo belongs to the European Healthy Cities Network and the international movement of Cittaslow and its retailing density is higher than the average when compared to similar cities of the same size. In the conduction of this case study research we carried out a two-stage empirical research (Yin, 2018): a qualitative and a quantitative study.

\section{A) Qualitative research}

The first part of the study was of an exploratory nature and consisted of seven in-depth interviews with different highranked officials of the town and town centre organizations. The purpose of this qualitative research was to gain a profound and detailed knowledge of the economic activity of the town. The interviewees held the following positions: (a) Mayor of the town council of Viana do Castelo, (b) President of the tourism entity Porto and north of Portugal, (c) President of the Business Association of Viana do Castelo, (d) Manager of Welcome Centre of Viana do Castelo, (e) Manager of EstaçãoViana shopping, (f) Manager of hotel Flor do Sal and (g) a Consulting Manager specialized in town centre research.

The main ideas highlighted by the interviewees were, in first place, the fact that the quality of the retail offer is closely related to the variety of the offer (shopping mix), the quality of the service and the promotional campaigns, town quality, accessibility, parking, cleaning, lighting, security and residential density. They considered these aspects are paramount for the good image of the town centre and the retail offer characteristics can position a town like shopping destination. The motivation for shopping is always present in the minds of visitors and tourists, and the shopping offer is deemed as part of a successful tourist package. It is even considered that there is a very close relationship between town centre and its retail. All interviewees thought that the strength of this influence could depend on the size of the town and the way it develops and evolves as a whole. And almost all the interviewees considered that town centre retail should be a brand. For this to happen, everyone considered it important that the actions be taken jointly involving the different actors that interact in town. Coordination and good performance of the different town Centre functions were highlighted: municipalities, trade associations, owners of spaces, merchants, tourist promoters, and although less frequently mentioned, parish boards, security forces and the media. In summary, the opinions of the different interviewees generally confirmed the trends in the bibliographic research. These interviews helped to build the questionnaire that served as the basis of quantitative research

\section{b) Quantitative research}

This part of the study consisted of collecting information through telephone surveys by CATI (computer assisted telephone interviewing) using the questionnaire developed for this study. A total number of 14 surveys takers were recruited and trained by market research firm Intercampus. Fieldwork for data acquisition was held between 17-072015 and 28-07-2015 in the areas of Alto Minho, Cávado, Ave and Área metropolitana do Porto. A total of 400 valid responses was obtained from 1117 total contacts (response rate: 35,81\%).

For the analysis of the data, SPSS software version 22.0 was used. Firstly, the sample was characterized using descriptive statistics techniques in the analysis of the questions characterizing the survey: sex, age, level of studies and employment status.

For the analysis of the remaining questions of the questionnaire, the techniques of descriptive statistical univaried by means of exploratory data analysis were used. To study the nature of the relationship between the values of two variables, the Pearson's linear correlation coefficient has been used. To study the association between the characteristics, and the image of the town of Viana do Castelo, and the image of the retail of the town centre, the chisquare test was used.

\subsection{Determination of the measurement scales of the model}

\section{a) Independent variables: accessibility, amenities, attractions and action}

The model brings together the critical aspects for the image of town retail in four main dimensions: accessibility; amenities; attractions and action. However, it is introduced in relation to the framework of 4 a's, supported by vital and viable town centre, characteristics included in the proposals of other authors: free parking and site design (HauserandKoppelman, 1979; Jones et al., 2016); town environment and mobility (D'Silva, 2018)and street conservation (Nevinand Houston, 1980). The item scan be observed in Table 2.

\section{b) Previous variable - Image of the Town Centre Retail of Viana do Castelo}


To measure this variable, we used a model suggested and tested by Yuksel (2007). In the model used by the author, it is considered that the attraction of the habitat of shopping tourism, which the author calls TSH - Tourism Shopping Habitat, depends on a set of three dimensions: environment; purchase emotions and the purchase value.

The author subdivides the emotions of the purchase, in pleasure and stimulation, and the value of purchase, in the affectivity and usefulness of the purchase. In the present study, because of the review of the literature, the use of TSH is extended to the entire town shopping zone, and it is considered that the attractiveness of the commercial zone is closely related to the image of the same. Based on these assumptions, the antecedent variable "Image of the town centre retail of Viana" indicators can be observed in Table 2.

\section{c) Variable Final - Image of town}

The scale of García-Gallego et al. (2015) was used to measure the final variable "Image of the town of Viana do Castelo", in turn an adaptation of the scale used by González and Villanueva (2001) which focused on the measurement of "perceptions about the origin of the destination". Applying the critical dimensions to the image of the town to Viana do Castelo we obtain the indicators shown in Table 2.

The items of these variables were all measured using a Likert-type Scale from 1(completely disagree) to 5 (completely agree).

Table 2. Definition of independent variables

\begin{tabular}{|c|c|c|}
\hline variables & Scope & Item \\
\hline \multirow{6}{*}{$\begin{array}{l}\text { Accessibili } \\
\text { ty }\end{array}$} & Location & "The location of the town centre retail zone is good" \\
\hline & Parking & "In the town centre it is easy to park" \\
\hline & $\begin{array}{l}\text { Pedestrianiza } \\
\text { t. }\end{array}$ & $\begin{array}{l}\text { "The pedestrian zone in the town centre is adjusted to the } \\
\text { dimension of the town" }\end{array}$ \\
\hline & Convenience & $\begin{array}{l}\text { "In the town centre it is easy to find what you want to } \\
\text { visit" }\end{array}$ \\
\hline & Mobility & $\begin{array}{l}\text { "Mobility on town centre roads for people with motor } \\
\text { difficulties is good" }\end{array}$ \\
\hline & $\begin{array}{c}\text { Public } \\
\text { Transport }\end{array}$ & "The town centre is easily accessible by public transport" \\
\hline \multirow{5}{*}{ Attractions } & Shops & "The town centre is a good place to go shopping" \\
\hline & $\begin{array}{l}\text { Food \& } \\
\text { beverage }\end{array}$ & "The town centre is a good place to eat out " \\
\hline & Night life & $\begin{array}{l}\text { "The town centre is a good place to have fun in the } \\
\text { evening" }\end{array}$ \\
\hline & Idleness & $\begin{array}{l}\text { "Spaces of entertainment in the town centre are enough } \\
\text { (cinemas, museums)" }\end{array}$ \\
\hline & Tourism & $\begin{array}{l}\text { "There are very good conditions to welcome visitors } \\
\text { tourists in the town centre" }\end{array}$ \\
\hline \multirow{5}{*}{ Amenities } & Cleaning & "The town centre is clean " \\
\hline & Security & "The town centre is a safe place" \\
\hline & Buildings & $\begin{array}{l}\text { "The town centre facades of buildings and public spaces } \\
\text { are in good condition" }\end{array}$ \\
\hline & Signage & $\begin{array}{l}\text { "The spaces of interest in the town centre are well } \\
\text { marked" }\end{array}$ \\
\hline & Environment & "The atmosphere in the town centre is pleasant" \\
\hline \multirow{3}{*}{ Action } & Activity & $\begin{array}{l}\text { "The activities carried out in the town centre are known } \\
\text { to the public" }\end{array}$ \\
\hline & Activity & $\begin{array}{l}\text { "The activities carried out in the town centre are of good } \\
\text { quality" }\end{array}$ \\
\hline & Activity & $\begin{array}{l}\text { "Activities carried out in the town centre are appropriate } \\
\text { for the size of the town" }\end{array}$ \\
\hline
\end{tabular}




\begin{tabular}{|c|c|c|}
\hline & Activity & $\begin{array}{l}\text { "The activities carried out in the town centre are well } \\
\text { communicated" }\end{array}$ \\
\hline & Entities & "The authorities of the town centre are dynamics" \\
\hline \multirow{5}{*}{$\begin{array}{l}\text { Image of } \\
\text { the town } \\
\text { centre of } \\
\text { Viana do } \\
\text { Castelo }\end{array}$} & Environment & $\begin{array}{l}\text { "The town centre of Viana and its retail are a pleasant } \\
\text { place to stroll" }\end{array}$ \\
\hline & Pleasure & $\begin{array}{l}\text { "Shopping in the town centre of Viana is an act of } \\
\text { pleasure" }\end{array}$ \\
\hline & Stimulus & "The retail in the town centre of Viana is exciting" \\
\hline & Usefulness & $\begin{array}{l}\text { "The retail offer of the town centre of Viana is adapted to } \\
\text { its needs" }\end{array}$ \\
\hline & Affectivity & $\begin{array}{l}\text { "I consider my time well spent when buying in the town } \\
\text { centre of Viana" }\end{array}$ \\
\hline \multirow{7}{*}{$\begin{array}{c}\text { Image of } \\
\text { town }\end{array}$} & Quality of life & "The quality of life in Viana is high". \\
\hline & $\begin{array}{l}\text { Educational } \\
\text { level }\end{array}$ & $\begin{array}{l}\text { "The educational level of the inhabitants of Viana is } \\
\text { high". }\end{array}$ \\
\hline & $\begin{array}{c}\text { Technological } \\
\text { level }\end{array}$ & "Viana do Castelo has an advanced level of technology" \\
\hline & $\begin{array}{l}\text { Richness of } \\
\text { the region }\end{array}$ & "Viana is a rich town in economic terms". \\
\hline & $\begin{array}{l}\text { Tourist } \\
\text { destination }\end{array}$ & "Viana is an attractive town as a tourist destination" \\
\hline & $\begin{array}{l}\text { Territory } \\
\text { management }\end{array}$ & "Viana is a town that is well managed" \\
\hline & $\begin{array}{l}\text { General } \\
\text { image }\end{array}$ & $\begin{array}{l}\text { "In general, the image that I have of Viana as a town is } \\
\text { positive" }\end{array}$ \\
\hline
\end{tabular}

Note: All the items were measured using a Likert-type Scale from 1 (completely disagree) to 5 (completely agree). Source: the authors

\section{Results}

After analyzing the responses to the questionnaire, the following results, shown in Table 3, were obtained:

\section{Table 3. Results}

\begin{tabular}{|c|c|c|c|}
\hline variables & Item & A verage & $\begin{array}{l}\text { Standird } \\
\text { Deviation }\end{array}$ \\
\hline \multirow{6}{*}{ Accessibility } & "The location of the town centre retail zone is good" & 4,30 & 0,84 \\
\hline & "In the town centre it is easy to park" & 3,44 & 1,31 \\
\hline & "The pedestrian zone in the town centre is adjusted to the dimension of the town" & 4,18 & 0,88 \\
\hline & "In the town centre it is easy to find what you want to visit" & 4,27 & 0,93 \\
\hline & "Mobility on town centre roads for people with motor difficulties is good" & 3,61 & 1,01 \\
\hline & "The town centre is easily accessible by public transport" & 3,65 & 1,02 \\
\hline \multirow{4}{*}{ Attractions } & "The town centre is a good place to go shopping" & 4,09 & 1,00 \\
\hline & "The town centre is a good place to eat out" & 4,27 & 0,96 \\
\hline & "The town centre is a good place to have fun in the evening " & 3,57 & 1,02 \\
\hline & "Spaces of entertainment in the town centre are enough (cinemas, museums)" & 3,51 & 0,97 \\
\hline
\end{tabular}




\begin{tabular}{|c|c|c|c|}
\hline & "There are very good conditions to welcome visitors / tourists in the town centre" & 4,56 & 0,74 \\
\hline \multirow{5}{*}{ Amenities } & "The town centre is clean" & 4,61 & 0,63 \\
\hline & "The town centre is a safe place" & 4,43 & 0,76 \\
\hline & "The town centre facades of buildings and public spaces are in good condition" & 4,15 & 0,85 \\
\hline & "The spaces of interest in the town centre are well marked " & 4,28 & 0,85 \\
\hline & "The atmosphere in the town centre is pleasant" & 4,62 & 0,61 \\
\hline \multirow{5}{*}{ Action } & "The activities carried out in the town centre are known to the public" & 3,64 & 0,92 \\
\hline & "The activities carried out in the town centre are of good quality" & 3,73 & 0,85 \\
\hline & "Activities carried out in the town centre are appropriate for the size of the town" & 3,71 & 0,90 \\
\hline & "The activities carried out in the town centre are well communicated" & 3,58 & 0,99 \\
\hline & "The authorities of the town centre are dynamics" & 3,62 & 0,88 \\
\hline \multirow{5}{*}{$\begin{array}{l}\text { Image of the } \\
\text { town centre } \\
\text { of Viana do } \\
\text { Castelo }\end{array}$} & "The town centre of Viana and its retail are a pleasant place to stroll" & 4,64 & 0,59 \\
\hline & "Shopping in the town centre of Viana is an act of pleasure" & 4,02 & 0,92 \\
\hline & "The retail in the town centre of Viana is exciting" & 4,26 & 0,86 \\
\hline & "The retail offer of the town centre of Viana is adapted to its needs" & 4,16 & 0,89 \\
\hline & "I consider my time well spent when buying in the town centre of Viana" & 4,16 & 0,89 \\
\hline \multirow{7}{*}{$\begin{array}{l}\text { Image of } \\
\text { town }\end{array}$} & "The quality of life in Viana is high". & 3,71 & 0,98 \\
\hline & "The educational level of the inhabitants of Viana is high". & 3,75 & 0,93 \\
\hline & "Viana do Castelo has an advanced level of technology" & 3,64 & 0,80 \\
\hline & "Viana is a rich town in economic terms". & 3,72 & 0,97 \\
\hline & "Viana is an attractive town as a tourist destination" & 4,63 & 0,72 \\
\hline & "Viana is a town that is well managed" & 3,92 & 0,96 \\
\hline & "In general, the image that I have of Viana as a town is positive" & 4,61 & 0,68 \\
\hline
\end{tabular}

Note: All the items were measured using a Likert-type Scale from 1 (completely disagree) to 5 (completely agree). Source: the authors

All of the statements that were scrutinized scored above $50 \%$ on the "partially agree" and "completely agree" scales. The results shown that the "The town centre of Viana and its retail are a pleasant place to stroll", with a degree of agreement of $94.5 \%$. Regarding the other statements, it stands out that "The retail in the town centre of Viana is exciting" which registers $78.5 \%$ level of agreement, "The retail offer of the town centre of Viana is adapted to its needs" obtains $74.8 \%$ and "I consider my time well spent when buying in the town centre of Viana" reaches $74.3 \%$. These results are in line with the work of Balsas(2004: 103), in which the author affirmed that 'the vitality of city centers depends very much on the dynamics of commerce there, even considering the decisive role of commerce' ... perhaps the most important critical component for livability of the town center'.

Analyzing the nature of the relationships between the different variables by applying Pearson's Coefficient of Correlation, we found that all of them are linearly related, albeit weakly, with a stronger relationship between the variables associated with the image of town commerce, "Shopping in the town centre is an act of pleasure" and "I consider my time well spent when buying in the town centre of Viana" $(0.5 \leq r<0.8$, more precisely $r=0.516)$. The items"The retail in the town centre of Viana is exciting"and "The retail offer of the town centre of Viana is adapted to its needs" $(0.5 \leq \mathrm{r}<0,8$, more precisely $\mathrm{r}=0,654)$ and also with "I consider my time well spent when buying in the town centre of Viana" $(0.5 \leq \mathrm{r}<0.8$, more precisely $\mathrm{r}=0.601)$. Among the items"Activities carried out in the town 
centre are appropriate for the size of the town"and "The activities carried out in the town centre are well communicated" $(0.5 \leq \mathrm{r}<0.8$, more precisely $\mathrm{r}=0.594)$.

Also, within the image of the city of Viana do Castelo there seems to be a moderate relationship between "It is an attractive town as a tourist destination" and "In general, the image that I have of Viana as a town is positive"" $(0.5 \leq \mathrm{r}<$ 0.8 , plus precisely $\mathrm{r}=0.605$ ).

Having completed the characterization of the sample and the different variables, we now present as conclusion the contrast of the hypotheses (Table 4). By applying the chi-square test (p-values), all null hypotheses (H0) are rejected. These results confirm our formulated hypotheses, which are all (H1 - H9) are accepted.

Table 4. Contrast of hypotheses

\begin{tabular}{lccc}
\hline \multicolumn{1}{c}{ Hypotheses } & P value & $\begin{array}{c}\text { Hypotheses } \\
\text { Contrast }\end{array}$ \\
\hline $\begin{array}{l}\text { H1: The town centre accessibility positively } \\
\text { influences the image of the town centre retail. }\end{array}$ &, 036 & $\begin{array}{c}\text { Accept } \\
\text { ed }\end{array}$ \\
$\begin{array}{l}\text { H2: The town centre accessibility positively } \\
\text { influences the image of the town. }\end{array}$ &, 001 & Accepted \\
$\begin{array}{l}\text { H3: An attractive town centre positively influences } \\
\text { the image of the town centre retail. }\end{array}$ &, 000 & Accepted \\
$\begin{array}{l}\text { H4: An attractive town centre positively influences } \\
\text { the image of the town. }\end{array}$ &, 000 & Accepted \\
$\begin{array}{l}\text { H5: The town centre amenities positively influence } \\
\text { on the image of the town centre. }\end{array}$ & 0,000 & Accepted \\
$\begin{array}{l}\text { H6: The town centre amenities positively influence } \\
\text { the image of the town. }\end{array}$ &, 000 & Accepted \\
$\begin{array}{l}\text { H7: The town centre management positively } \\
\text { influences the image of the town centre retail. }\end{array}$ &, 000 & Accepted \\
$\begin{array}{l}\text { H8: The town centre management positively } \\
\text { influences the image of the town. }\end{array}$ & Accepted \\
$\begin{array}{l}\text { H9: A good image of the town centre retail } \\
\text { positively influences the image of the town. }\end{array}$ &, 000 & Accepted \\
\hline
\end{tabular}

\section{Discussion}

This research confirms that the existence of a successful town retail zone depends on many attributes. The quality of the zone where it is located is a crucial dimension. It was argued that this town quality depends on other factors such as accessibility, amenities, attractions and action.

Within the accessibility factor - the item "sufficient number of parking zones" was the most valued, followed by the location of the commercial area in the centre and the ease of access from public transport. As for the attractiveness factor, the most valued characteristics were the variety of retails in the shopping zone in question, followed by the presence of many establishments and finally the quality of the products. Variety, quantity, and quality are also referred to in the literature as highly valued in attracting demand (Leoand Philippe, 2002; Runyan and Huddleston, 2006).

Regarding amenities, the most valued item was security, followed by the appropriate signaling of the town zone and the town furniture. Animations are also undervalued since they generate pedestrian traffic in the zone, but do not necessarily translate into higher sales for the establishments (Forsberg, Medway, Warnaby, 1999). The less valued factor has to do with the aspect of buildings since they are ornamental elements and do not motivate shopping (Leo and Philippe 2002; Warnaby and Medway, 2004). The action items were the less valuated compared to the items of the rest of the factors in the model. Due to that fact, the promotional and communication activities of town center, such as the need to carry out frequent advertising, promotion and communication campaigns, among other things, should be improved. The professionalization of town centre management is considered relevant. In the study, although the respondents considered the importance of this factor it appears as the least valued. For the interviewees the need for an entity to assume responsibility for this coordination is expressed by all. The importance of cooperation between the 
different town centre stockholders is latent. They appear as essential players: the local trade association, the municipality and the tenants.

The importance of town centre retail, as a privileged actor in the dialogue with the town, is common in the set of answers. The recognition of this pivotal role is unanimous, being, as we noted, a determining factor in the influence on the image that a visitor/tourist make of a town. Every interviewed agreed about the need for an attractive, dynamic and strong retail. The articulation and strategic coordination of commercial activity based on town planning and shopping promotion are considered as strategic vectors for the success of retail.

Another factor considered decisive is the quality of the available retail offer: the quality and variety of products and services offered together with the decoration and organization of shops and commercial promotion. In summary, the opinions of the different interviewees confirmed the trends identified in the bibliographic review and helped to build the model that served as the basis for quantitative research.

Retail integrated holistically with the town centre environment deserves great attention. The results point that the variable image of town centre is highly valued by the respondents. The direct influence of the image of the town centre retail on the image of the town has been demonstrated in this research. This analysis supports the research of Serrano, Tajada, and Orbegozo (2006), stating that commercial functions also play an important role in the functioning and configuration of the social life of the town.

The town centre retail is of paramount importance in the commercialization and promotion of the town centre and of the whole town. This is evidenced by the analysis of the variable "action" in the study as well as by the interviews. It is observed in most of the surveys that those who have visited one or more times the city have in general a more positive opinion about the image of the city. This is understandable if we consider the complexity of the image dimension dependent on many factors- and the on-site experience which is one of the most important factors.

\section{Conclusion and future research}

This study has revealed a number of relevant findings concerning the role of town centre retail in the town image. Some factors such as the tendency to build huge out-of-town superstores has put town centres retail under threat. However, keeping this retail alive seems to be necessary in order to foster town centre's vitality since town centres are at the heart of every town. Specifically we have studied the role of town centre retail in the image of the town, with purposes of attracting visitors and tourists, through the framework of the 4 A's (DoE, 1994).

The relevant influence of the factors affecting the image of the town centre retail mentioned in the literature was confirmed. The results of this research, through the application of an adaptation of the framework of the 4 A's, have evidenced the factor Amenities as the most valued, closely followed by Attractions and Accessibility. These factors determine the quality of the zone where the town centre retail is located which was highlighted (the zone quality) as a crucial dimension. Thus, according to our study, we can conclude that a town retail offer influences potential consumer (tourists and visitors) decision to visit a destination through its image, formed by the conjunction of the variables studied.

However, the case study being a very holistic and comprehensive methodology, it is also a specific type of research that can generate some difficulties in terms of external validity when generalizing the research results. A next step would be to expand the universe to another reference audience, so we can better contrast the component variables of the model. In this sense, it would be convenient to collect the opinions of residents in the town and compare with the results now obtained. Another analysis to consider in a further stage of this research may involve to test the model with different techniques.

\section{Bibliography}

Andersson, G, Abbasian, S (2018) Analysis Dimensions of City Destination Character and Image Positioning. Almatourism-Journal of Tourism, Culture and Territorial Development 9(17): 33-54.

A.T.C.M. (2018) Association of Town Centre Management. The effectiveness of town centre. https://www.atcm.org. Ashworth, G J, Voogd, H (1990) Selling the city: marketing approaches in public sector urban planning. Belhaven Press.

Avraham, E (2004) Media strategies for improving an unfavorable image of the town. Cities 21(6): 471-479.

Balsas, C (2002) Townismo shopping e parcerias público-privado. Observatório do Comércio, Lisboa.

Balsas, C (2004) Town centre regeneration in the context of the 2001 European capital of culture in Porto, Portugal. Local Economy 19(4): 396-410.

BCSC, (2002).Centre / British Council of Shopping Centre 
Bigné, J, Sánchez, M, Sánchez, J (2001) Tourism image, evaluation Variables and after purchase behavior: Interrelationships. Tourism Management 22(6): 607- 616.

Brown, S (1989) Retail location theory: The legacy of Harold Hotelling. Journal of Retailing 65(4): 450-470.

Cerdá Suárez, L M, Fernández Nogales, A, Rebollo Arévalo, A (2007) Atributos para el éxito de una zona comercial. Distribución y consumo 17(95): 16-31.

Collis, C, Berkeley, N, Fletcher, D, R (2000) Retail decline and policy response in district shopping centre. Town Planning Review 1(2): 149-16.

Diamond, J, Liddle, J, Southern, A, Osei, O (2010) Urban Regeneration Management: International Perspectives, Routledge.

Díaz, M R (2004) Determinación de la imagen de los centros comerciales. Información Comercial Española, ICE: Revista de Economía (815): 241-260.

Dinardi, C (2015) Cities for sale: Contesting city branding and cultural policies in Buenos Aires. Urban Studies 54(1): 85-101.

Dobni, D, Zinkhan, G M (1990) In search of brand image: A foundation analysis. Advances in Consumer Research 17(1): 110-119.

DoE - Department of the Environment of UK (1994). Vital and Viable town Centre: meeting the challenge. Urban and Economic Development Group (URBED). ISBN 0-11-751943-5

D'Silva, K, Jayarajah, K, Noulas, A, Mascolo, C, Misra, A (2018) The Role of Urban Mobility in Retail Business Survival. Proceedings of the ACM on Interactive, Mobile, Wearable and Ubiquitous Technologies 2(3).

Eghbali, N, Kharazmi, O A, Rahnama, M R (2015) Assessing Effective Factors for the Formation of Image of the town in Mashhad from the Viewpoint of Tourists. Cumhuriyet Science Journal 36(3):133-148.

Fernandes, J A R, Cachinho H, Ribeiro, C V (2001) Comércio Tradicional em Contexto town. Dinâmicas de Modernização e Políticas Públicas. Gabinete de Estudos para o Desenvolvimento e Ordenamento do Território. Faculdade de Letras da Universidade do Porto.

Forsberg, M, Medway, D, Warnaby, G (1999) Town Centre Management by Cooperation. Evidence from Sweden. Cities 16 (5): 337-354.

Fotheringham, A S, O’Kelly, M E (1989) Spatial Interaction Models: Formulations and Applications. Dordrecht: Kluwer Academic Publishers.

García-Gallego, J M, Chamorro-Mera, A, García-Galán, M M (2015) The region-of-origin effect in the purchase of wine: The moderating role of familiarity. Spanish Journal of Agricultural Research, 13(3).

Ghosh, A, McLafFerty, S L (1987) Location Strategies for Retail and Service Finns. D. C. Heath.

González, M J, Villanueva, M L (2001) La receptividad de los consumidores navarros hacia los productos de origen regional y nacional. In Navarra y la sociedad del conocimiento: actas del congreso, Gobierno de Navarra, 533550.

Hall, T, Hubbard, P (1998) The entrepreneurial city: geographies of politics, regime, and representation. John Wiley \& Sons.

Hauser, J R, Koppelman, F S (1979) Alternative perceptual mapping techniques: Relative accuracy and usefulness. Journal of Marketing Research16: 495-506.

Ingene, C A (1984) Productivity and Functional Shifting in Spatial Retailing: Private and Social Perspectives. Journal of Retailing and Consumer Services 60(3): 15-26.

Jones, C, Al-Shaheen, Q, Dunse, N (2016) Anatomy of a successful high street shopping centre. Journal of Urban Design 21(4): 495-511.

Kavaratzis, M (2004) From town marketing to town branding: towards a theoretical framework for developing town brands. Place Branding1(1): 58-73.

King, J (2002) Destination marketing organizations-Connecting the experience rather than promoting the place. Journal of Vacation Marketing 8(2): 105-108.

Kinley, T, Kim, Y K, Forney, J (2002) Tourist-destination shopping centre: An importance-performance analysis of attributes. Journal of Shopping Centre Research, 51-72.

Kotler, P (1999) Political Marketing--Generating Effective Candidates, Campaigns, and Causes. In Handbook of Political Marketing (pp. 3-18). Sage Publications.

Kotler, P, Armstrong, G (2018) Principles of marketing. 17th ed. Pearson.

Las Casas, A L, Silverio, A P M (2015) Strategic image management: The image of the city of São Paulo/SP. African Journal of Business Management 9(6): 288-297.

Leo, P Y, Philippe J (2002) Retail centres: Location and consumer's satisfaction. Service Industries Journal 22 (1): 122-146.

Levy, M, Weitz, B A (2007) Retailing Management. McGraw-Hill Irwin, Boston, MA. 
Moscardo, Gianna (2008) Understanding resident perceptions of tourism impacts. In: Proceedings of 14th Asia Pacific Tourism Association Annual Conference, pp. 592-601. From: Tourism \& Hospitality in Asia Pacific, 9-12 July 2008, Bangkok, Thailand.

Neacşu, M C, Neguţ, S (2012) Image of the city-Operational Instrument in urban Space Management-A Romanian Sample. Advances in Spatial Planning New Economy 11: 106-113.

Nair, S (2018) A study on social commerce as a change agent in retail communication. International Research journal of Commerce, Management and Social Science 8: 1-12.

Nevin, J R, Houston, M J (1980) Image as a component of attraction to intraurban shopping areas. Journal of retailing 56(1): 77-93.

Paddison, R (1993) City Marketing, Image Reconstruction and Urban Regeneration. Urban Studies 30(2): 339-349.

Peixoto, P (2003) Centros históricos e sustentabilidade cultural das cidades. Sociologia 13: 211-226.

Robertson, K, Ryan, B (2004) Town centre Development: On the Metropolitan Fringe. Economic Development Journal Fall, 16-24.

Runyan, R C, Huddleston, P (2006) Getting customers downtown: the role of branding in achieving success for central business districts. Journal of Product \& Brand Management 15(1): 48-61.

Serrano, L M, Tajada, S, Orbegozo, U T (2006) Asociacionismo comercial espacial y revitalización urbana. Distribución y consume 16(86): 48-60.

Shaw, G, Williams, A (1994) Critical Issues in Tourism: A Geographical Perspective. Oxford: Blackwell.

Stubbs, B, Warnaby, G, Medway, D (2002) Marketing at the public/private sector interface; town centre management schemes in the south of England. Cities 19(5): 317-326.

Solanas, A, Salafranca, L, Fauquet, J, Núñez, M I (2005) Estadística descriptiva en Ciencias del Comportamiento.Madrid: Thompson.

Trueman, M, Klemm, M, Giroud, A (2004) Can a city communicate? Bradford as a corporate brand. Corporate Communications: An International Journal 9(4): 317-330.

Wang, J (2009) 'Art in capital': Shaping distinctiveness in a culture-led urban regeneration project in Red Town, Shanghai. Cities 26(6): 318-330.

Ward, S V (1998) Selling Places: The Marketing and Promotion of Towns and Cities. London: E.\&F.N. Spon,18502000.

Warnaby, G (1998) Marketing UK cities as shopping destinations: problems and prospects. Journal of Retailing and Consumer Services 5(1): 55-58.

Warnaby, G (2000) Process, content and context considerations influencing the marketing of urban zones as shopping destinations, Management and Business Working Papers, Graduate Business School of the Manchester Metropolitan University.

Warnaby, G, Davies, B J (1997) Commentary: cities as service factories? Using the servuction system for marketing cities as shopping destinations. International Journal of Retail \& Distribution Management 25(6): 204-210.

Warnaby, G, Medway, D. (2004) The role of place marketing as a competitive response by town centre to out-of-town retail developments. The International Review of Retail, Distribution and Consumer Research 14(4): 457-477.

Warnaby, G, Bennison, D J, Davies, B J, Hughes, H L (2003) How important is retail in the marketing of towns and cities? Public sector perspectives. European Retail Digest, Oxford Institute of Retail Management.

Warnaby, G, Bennison, D, Davies, B J, Hughes, H (2002) Marketing UK Towns and cities as shopping destinations. Journal of Marketing Management 18(9-10): 877-904.

Westwood, S and Williams, J M (2018) Imagining cities. Routledge.

Yin, R K (2018) Case Study Research and Applications. Design and Methods. Sage.

Yuksel, A (2007) Tourist shopping habitat: effects on emotions, shopping value and behaviours. Tourism Management 28(1): 58-69. 